\title{
Ingrowing Toenails and Tetraplegia
}

David Jaffray, M.B., F.R.C.S. (Ed) and W. El Masri, F.R.C.S. (Ed).

Midlands Spinal Injuries Unit, Robert fones and Agnes Hunt Orthopaedic Hospital, Oswestry, Shropshire, U.K.

\section{Summary}

Nearly half the tetraplegic patients examined in a spinal injuries clinic had suffered ingrowing of the great toenail only after the injury to their spinal cord. This article describes the features of this common condition.

Key words: Ingrowing toenails; Tetraplegia.

\section{Introduction}

Ingrowing toenails are a very common problem in patients with spinal cord injuries. The complications of an apparently minor problem can be serious. The purpose of this paper is to identify the type of patient likely to develop ingrowing of the great toenail and to clarify the aetiology and frequency of this condition.

\section{Material}

Fifty tetraplegic outpatients were reviewed and questioned about their toenails. A further 14 inpatients with tetraplegia, who had ingrowing of their great toenails, were included in the study. We defined ingrowing of the toenail to be clinically significant only when an edge of the great toenail had caused inflammation, bleeding or abscess formation.

\section{Results}

Twenty-two of the 50 tetraplegic outpatients had suffered ingrowing of their great toenails since their spinal cord injury (Table 1). Twenty-one of the 22 outpatients who had suffered ingrowing of their great toenails had a complete cord lesion. All the 50 outpatient tetraplegics had cord lesions at either the C5 or C6 level. All the 14 inpatient tetraplegics with ingrowing toenails had 
Table 1 Features of the outpatient tetraplegics with ingrowing toenails

\begin{tabular}{|c|c|c|c|c|c|}
\hline Subject & $\begin{array}{l}\text { Interval } \\
\text { from cord } \\
\text { injury until } \\
\text { ingrowing } \\
\text { toenail } \\
\text { developed }\end{array}$ & $\begin{array}{c}\text { Recurrences } \\
\text { R }\end{array}$ & $\begin{array}{c}\text { Brittle } \\
\text { nails } \\
\text { B }\end{array}$ & $\begin{array}{l}\text { Deformity of } \\
\text { nails } \\
\text { (D) }\end{array}$ & $\begin{array}{l}\text { Spasms } \\
\text { in } \\
\text { affected } \\
\text { limb } \\
(\mathrm{S})\end{array}$ \\
\hline 1 (V.H.) & 10 years & $\mathrm{R}$ & B & - & - \\
\hline 2 (T.H.) & 2 years & $\mathrm{R}$ & $\mathrm{B}$ & $\mathrm{D}$ & $S$ \\
\hline 3 (A.G.) & 7 months & - & B & $\mathrm{D}$ & - \\
\hline 4 (P.D.) & 1 year & - & B & $\mathrm{D}$ & - \\
\hline 5 (G.J.) & 10 months & $\mathrm{R}$ & B & 一 & - \\
\hline 6 (J.W.) & 3 years & $\mathrm{R}$ & 一 & - & $S$ \\
\hline 7 (N.J.) & 7 years & - & B & - & - \\
\hline 8 (R.C.) & 6 months & $\mathrm{R}$ & B & - & - \\
\hline 9 (A.S.) & 3 years & $\mathrm{R}$ & - & - & - \\
\hline 10 (D.L.) & 1 year & - & B & - & $S$ \\
\hline 11 (B.R.) & 7 months & - & - & - & - \\
\hline 12 (B.S.) & 8 years & 一 & - & 一 & - \\
\hline 13 (B.B.) & 2 years & - & B & - & - \\
\hline 14 (J.C.) & 3 years & $\mathrm{R}$ & B & $\mathrm{D}$ & - \\
\hline 15 (A.F.) & 5 years & $\mathrm{R}$ & B & - & $S$ \\
\hline 16 (A.S.) & 8 months & $\mathrm{R}$ & B & - & - \\
\hline 17 (M.H.) & 3 years & $\mathrm{R}$ & B & - & - \\
\hline 18 (R.A.) & 8 years & $\mathrm{R}$ & $\mathrm{B}$ & - & - \\
\hline 19 (F.S.) & 2 months & $一$ & B & 一 & - \\
\hline 20 (J.T.) & 4 years & $\mathrm{R}$ & $\mathrm{B}$ & - & - \\
\hline 21 (F.G.) & 9 years & - & B & - & - \\
\hline 22 (M.N.) & 3 months & $\mathrm{R}$ & B & - & \\
\hline
\end{tabular}

Table 2 Features of the inpatient tetraplegics with ingrowing toenails

\begin{tabular}{|c|c|c|c|c|c|}
\hline Subject & $\begin{array}{l}\text { Interval } \\
\text { from cord } \\
\text { injury until } \\
\text { ingrowing } \\
\text { toenail } \\
\text { developed }\end{array}$ & $\begin{array}{l}\text { Recurrences } \\
\text { (R) }\end{array}$ & $\begin{array}{l}\text { Brittle } \\
\text { nails } \\
\text { (B) }\end{array}$ & $\begin{array}{c}\text { Deformity } \\
\text { of } \\
\text { nails } \\
\text { (D) }\end{array}$ & $\begin{array}{l}\text { Spasms } \\
\text { in } \\
\text { affected } \\
\text { limb } \\
\text { (S) }\end{array}$ \\
\hline 1 (E.C.) & 8 years & $\mathrm{R}$ & B & $\mathrm{D}$ & - \\
\hline 2 (L.P.) & 5 years & $\mathrm{R}$ & - & - & $S$ \\
\hline 3 (J.C.) & 7 years & $\mathrm{R}$ & B & - & - \\
\hline 4 (S.S.) & 1 year & $\mathrm{R}$ & B & $\mathrm{D}$ & - \\
\hline 5 (C.C.) & 1 year & $\mathrm{R}$ & B & - & $S$ \\
\hline 6 (G.K.) & 2 years & $\mathrm{R}$ & $\mathrm{B}$ & - & - \\
\hline 7 (I.F.) & 5 years & $\mathrm{R}$ & B & - & - \\
\hline 8 (M.H.) & 1 year & $\mathrm{R}$ & $\mathrm{B}$ & - & $S$ \\
\hline 9 (G.A.) & 6 months & - & B & - & - \\
\hline 10 (S.H.) & 6 months & - & - & - & $S$ \\
\hline 11 (T.B.) & 5 months & - & - & - & - \\
\hline 12 (M.W.) & 7 months & $\mathrm{R}$ & B & - & - \\
\hline 13 (D.P.) & 6 months & - & B & - & - \\
\hline 14 (S.R.) & 10 months & $\mathrm{R}$ & - & - & - \\
\hline
\end{tabular}

complete cord lesions (Table 2). Of the 36 patients that had suffered ingrowing toenails, 28 patients had brittle nails, seven noted an increase in the curvature of their nails and 23 had recurrent ingrowing of the great toenail. Only two patients had suffered from ingrowing toenails prior to their spinal cord injury. 
Five of the inpatient tetraplegics had pus under their ingrowing great toenails. Two of these patients grew the same bacteria on cultures of their urine and from their toes.

Eight patients noticed increased spasticity in the limb affected by the ingrowing toenail. One patient had dramatic relief of spasticity after his nail was removed. The other seven patients thought they were improved after removal of their great toenail but were unable to quantify improvement.

\section{Discussion}

Ingrowing of the great toenail is a common condition. Medical interest has tended to focus on the treatment rather than the aetiology of ingrowing toenails. Perhaps this explains the poor results of surgical treatment of ingrowing toenails. (Palmer and Jones, 1979). Certain factors such as excessive curvature of the toenail and incorrect chiropody are known to be important in the aetiology of ingrowing toenails (Lawee and Freebairn, 1984). Ingrowing toenails are very common in patients with a spinal cord injury.

This study was confined to patients with an injury to the cervical spinal cord. It is our impression that ingrowing of the great toenail is less common in paraplegia than in tetraplegia. Forty-four per cent of the tetraplegic outpatients had suffered ingrowing of their great toenail. The frequency of ingrowing toenails in the general population is not known, but it is unlikely to be as common as in tetraplegia. The high incidence of ingrowing toenails in tetraplegia suggests that the effects of the spinal cord injury are related to the subsequent development of ingrowing toenails.

In our series the earliest that a great toenail started to ingrow after injury to the spinal cord was 2 months. No patient developed ingrowing of the great toenail during the initial period of bed rest. Gravity would appear to be a factor in the development of an ingrowing great toenail in a tetraplegic patient. There was great variance in the time of onset on the ingrowing great toenail ( 2 months -10 years). Twenty-six per cent of our out patient tetraplegics had recurrent ingrowing of their great toenails. There was no relationship between the time of onset of ingrowing of the great toenail and recurrent ingrowing of the great toenail.

Most of the patients $(87 \%)$ with ingrowing of the great toenail have noted that their nails had become brittle and easily broken since the injury to their spinal cord. Often the nail breaks transversely (Fig. 1) and the remnant then ingrows. When the nail is more deformed with an increased curvature, then the edges of the nail can penetrate the skin of the toe (Fig. 2). Five of the 22 outpatients attributed this as the cause of their ingrowing toenails.

Two patients attributed the ingrowing of the great toenails to tight footwear. None of our patients had a deformity of the toes which could predispose to ingrowing toenails. All our patients had marked trophic changes in the skin of the toes with absent sweating. There is no doubt that such trophic skin can be easily traumatised. As all our patients are chairbound for most of the day, gait is not a factor in the development of ingrowing toenails in the tetraplegic patient. Ingrowing of a toenail has been reported in a toe transferred to a hand to act as a thumb. (Sadr and Schenck, 1982). 


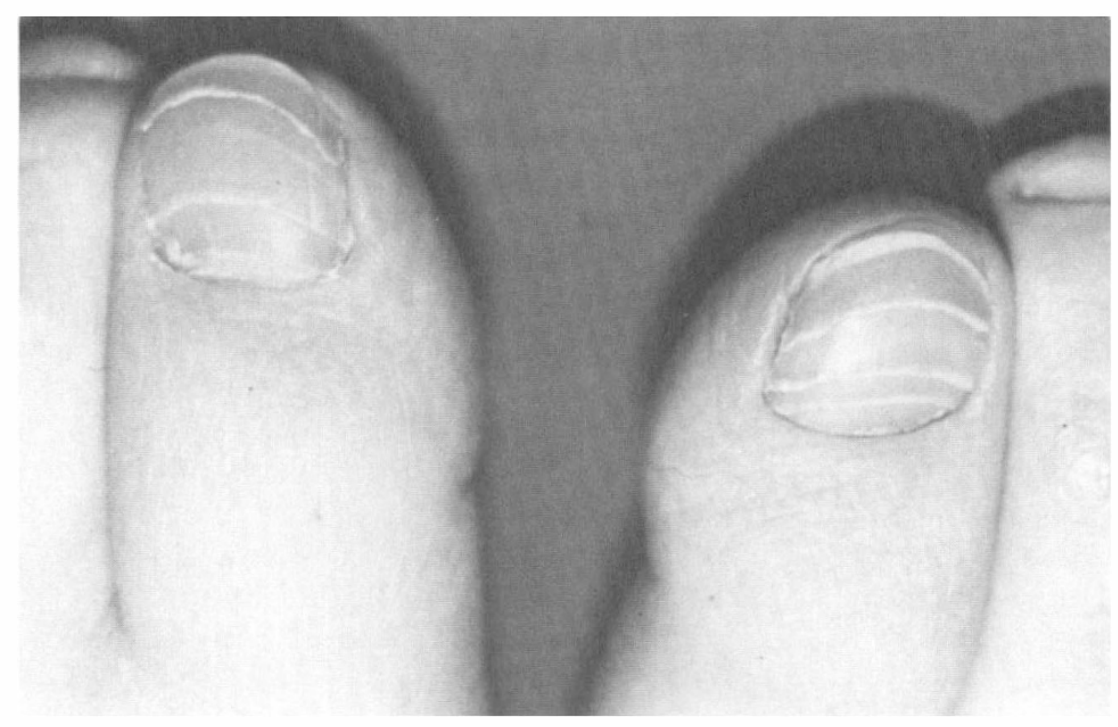

Figure 1. Multiple transverse fractures of the nail.

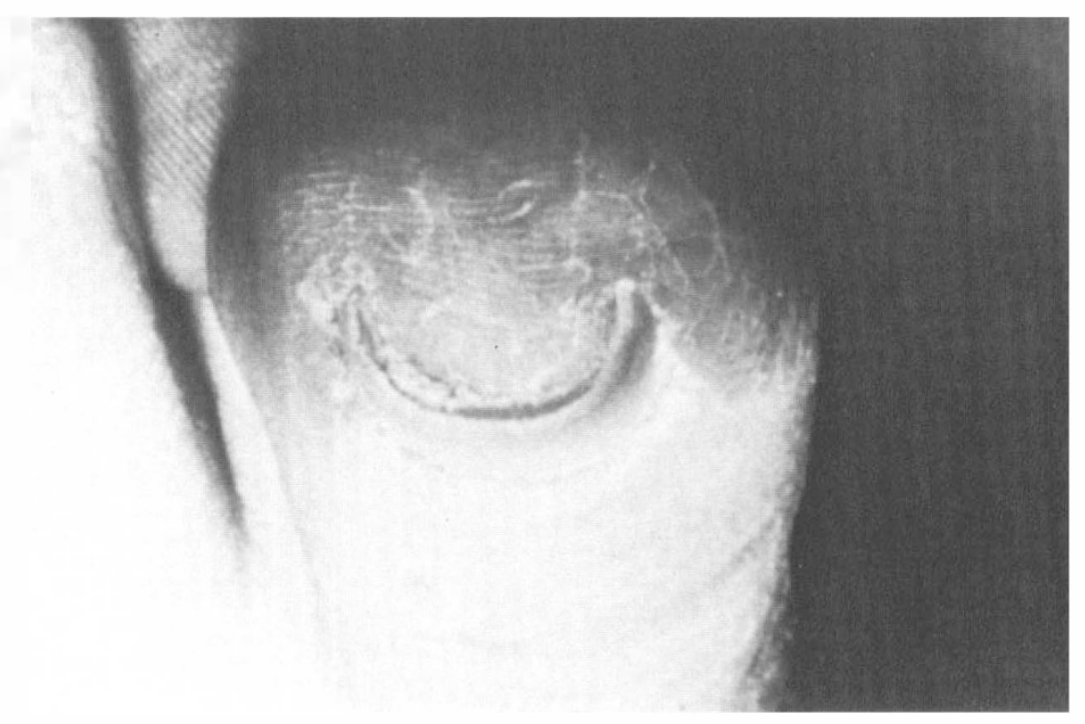

Figure 2. Increased curvature of the toenail.

The outpatients had their ingrowing great toenails treated by either chiropodists or by their relatives. A variety of treatments all produced early healing. Eight patients had noted an increase in the spasticity associated with their ingrowing toenail. We could not distinguish between those patients likely to develop spasticity as a result of their ingrowing toenail from those patients whose ingrowing toenail was only a problem of localised inflammation. Simple intermittent elevation of the nail corner, using a swabstick soaked in iodine 


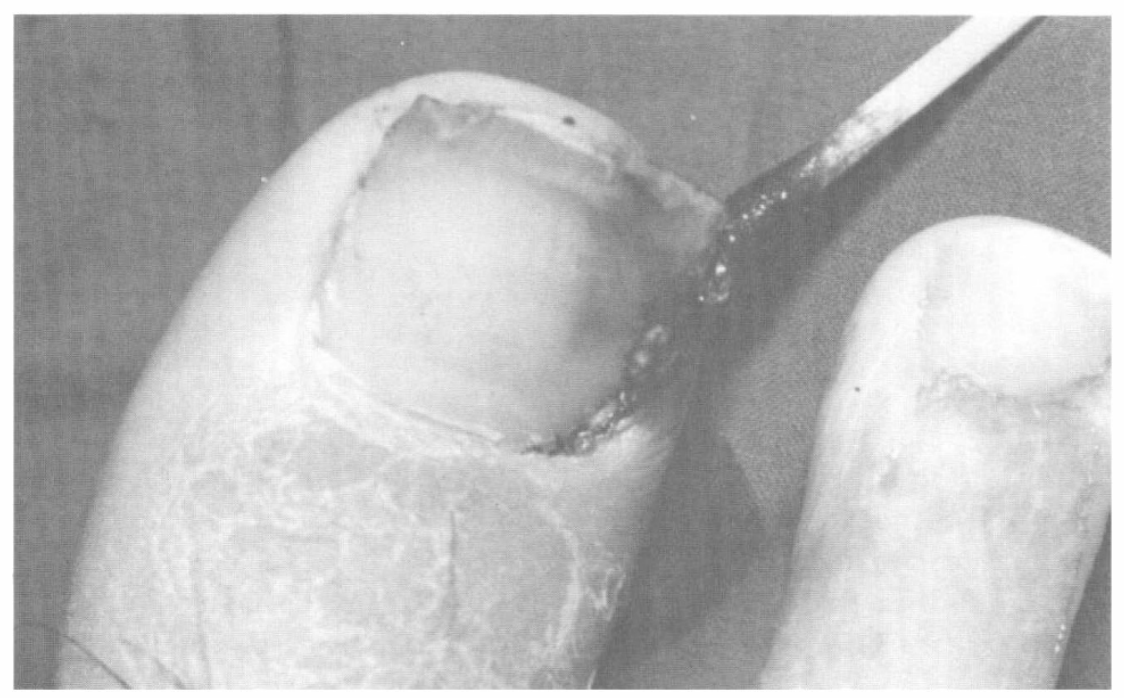

Figure 3. A swabstick elevates the ingrowing toenail.

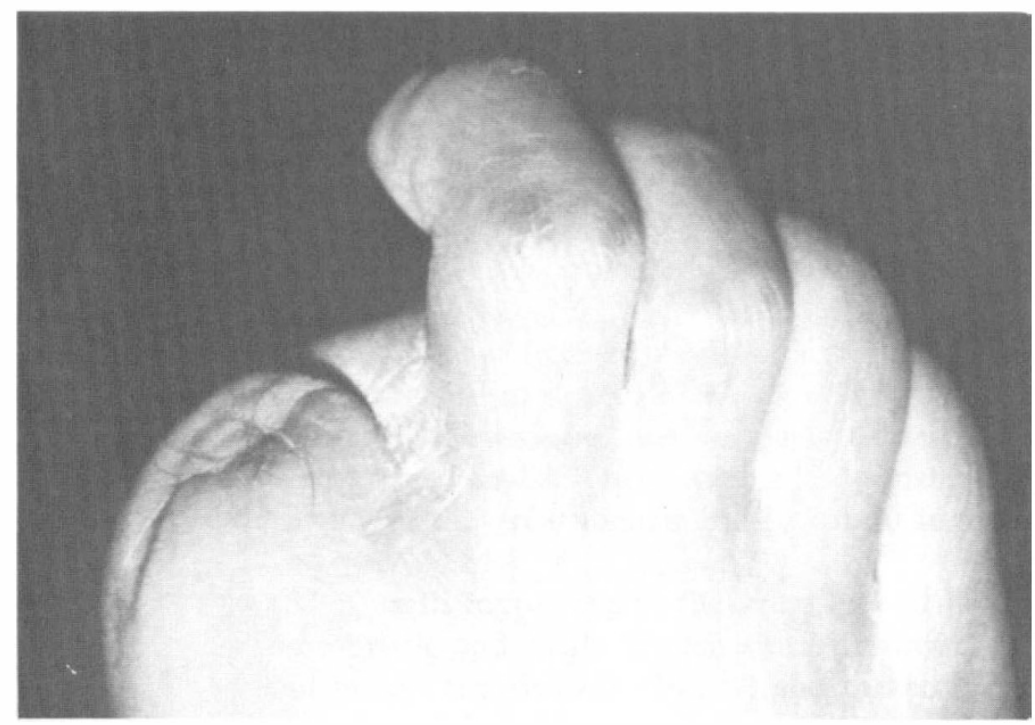

Figure 4. Amputation of the great toe because of chronic osteomyelitis.

(Fig. 3) until the nail covers the whole pulp of the great toe and then good chiropody will prevent recurrent ingrowing of the great toenail. (Lawee and Freebairn, 1984). Many of the surgical treatments used to treat ingrowing toenails have a high failure rate (Antrum, 1984; Palmer and Jones, 1979) and we would recommend radical treatment of the nail bed only for severe recurrent problems. 


\section{Conclusions}

Our series is too small to allow firm conclusions to be made. However in this series of 50 consecutive outpatient tetraplegics interviewed, 44 per cent had suffered ingrowing toenails since their spinal cord injury. All but one patient had a complete cord injury. Ingrowing of the toenail occurred after the initial period of bed rest in all but one patient. More than half the patients with ingrowing toenails had a recurring problem. Most of the patients with ingrowing toenails had brittle, easily broken nails which together with the effects of gravitational oedema on atrophic skin may be the main predisposing factors. We suspect that it may be exacerbated by the strong spasms of the toe flexors forcing the pulp of the toes against the sole of the shoe. The edges of the nail can then be driven into the ischaemic pulp. Ingrowing toenails in tetraplegia are usually little more than a nuisance but they can lead to a local chronic sepsis (Fig. 4) or a systemic infection with increased spasticity.

\section{Résumé}

Près de la moitié des Tétraplégiques examinés dans un hôpital qui traite les accidents à la colonne vertébrale, avait souffert d'un ongle incarné après la blessure de leur colonne vertébrale. Cet article dècrit les caractéristiques de ce problème courant.

\section{Zusamimenfassung}

Fast die Hälfte son den Tetraplegie Patienten, die in einer Klinic für Rückgratsschaden untersucht worden, habten an Einwachsung des grossen Sehennagels gelitten nur nach den verletzen des Rükkenmarkes.

Dieser Artikel beschreibt die Erscheinungsformen dieses häufigen Sustandes.

\section{References}

ANTRUM RA 1984 Radical excision of the nailfold for ingrowing toenail. Journal of bone and joint surgery 66B, 1:63-65.

LAWEE D, FreEbairn C 1984 An illustrated guide to toenail disorders. Modern Medicine 29:29-31.

PALMER BV, Jones A 1979 Ingrowing toenails: the results of treatment. British Journal of Surgery 66:575-576.

SADR B, SCHENCK RR 1982 Ingrowing nail of a transplanted toe. The Hand 14:337. 